\title{
KONFLIK SARA PADA PILKADA DKI JAKARTA DI GRUP WHATSAPP DENGAN ANGGOTA MULTIKULTURAL
}

\author{
Tiara Kharisma \\ Arsip Nasional Republik Indonesia \\ Jl. Ampera Raya No. 7, Jakarta Selatan, DKI Jakarta, 12560, Indonesia \\ No.Tlp/HP: 081210379773 \\ E-mail: tiarakharisma@yahoo.com
}

Naskah diterima tanggal 15 Juni 2017, direvisi tanggal 13 September 2017, disetujui tanggal 18 September 2017

\section{SARA CONFLICT OF THE DKI JAKARTA GOVERNOR ELECTION IN WHATSAPP GROUP WITH MULTICULTURAL MEMBERS}

\begin{abstract}
The diversity of SARA (refers to ethnicity, religion, race and inter-group relations) in Indonesia raises a multicultural society. In everyday life, intercultural communication is inevitable. Social media becomes one of the mediums used for intercultural communication. In multicultural societies, SARA issue is the main factor causing conflict. Likewise, what happened during Governor Election of DKI Jakarta in 2017, where the issue of SARA is widespread through WhatsApp group with heterogeneous group members. This study aims to determine the conflict management of SARA issues in the Governor Election of DKI Jakarta in 2017 on WhatsApp groups with multicultural members, towards qualitative approaches with data collection techniques through interviews and literature studies. The conflict management theory framework from Martin and Nakayama guides researchers in discussing this study. The results of the research indicate that conflicts occur because there are group members who convey the message, not from the similarity of group members, such as the interests and the initial goal of the formation of the group. The message is spread by assuming a form of defense against a religion. When conflicts occur, the conflict management strategy adopted is a compromising and avoiding strategy. In the group, there are members who act as cultural brokers.
\end{abstract}

Keywords: conflict, WhatsApp group, multicultural.

\begin{abstract}
Abstrak. Keanekaragaman SARA di Indonesia melahirkan masyarakat multikultural. Dalam kehidupannya, komunikasi antarbudaya tidak dapat dihindarkan. Salah satu medium dalam melakukan komunikasi antarbudaya adalah media sosial. Pada masyarakat multikultural isu SARA menjadi faktor utama penyebab terjadinya konflik. Di Pilkada DKI Jakarta 2017, isu SARA di grup WhatsApp marak menyebar termasuk anggota grup yang heterogen. Penelitian ini bertujuan untuk mengetahui pengelolaan konflik isu SARA pada Pilkada DKI Jakarta 2017 di grup WhatsApp dengan anggota multikultural. Penelitian ini menggunakan pendekatan kualitatif dengan teknik pengumpulan data melalui wawancara dan studi literatur. Dalam membahas penelitian ini, peneliti menggunakan kerangka teori manajemen konflik dari Martin dan Nakayama. Hasil penelitian menunjukkan bahwa konflik terjadi karena ada anggota grup menyampaikan pesan bukan berangkat dari kesamaan anggota grup, yakni kepentingan dan tujuan awal dibentuknya grup. Pesan disebarkan dengan menganggap wujud pembelaan terhadap suatu agama. Ketika konflik terjadi, strategi pengelolaan konflik yang diterapkan adalah strategi mengompromikan (compromising) dan menghindar (avoiding). Dalam grup terdapat anggota yang berperan sebagai cultural brokers.
\end{abstract}

Kata kunci: konflik, grup WhatsApp, multikultural. 


\section{PENDAHULUAN}

Keanekaragaman suku, agama, ras, dan antargolongan (SARA) di Indonesia menjadi salah satu keunikan tersendiri bagi bangsa Indonesia. Keanekaragaman di satu sisi memiliki dampak positif karena menunjukkan kekayaan budaya yang dimiliki bangsa Indonesia, tetapi di sisi lain dapat menjadi salah satu potensi terjadinya konflik antarbudaya. Keanekaragaman juga melahirkan masyarakat yang multikultural di Indonesia.

Dalam kehidupan masyarakat yang multikultural, tidak dapat dielakkan anggota dari suatu kelompok melakukan pertukaran pesan ataupun informasi dengan anggota kelompok lainnya. Dalam proses ini, komunikasi antarbudaya tidak mungkin dihindarkan. Komunikasi antarbudaya terjadi ketika seseorang dari satu budaya memproduksi pesan untuk dikonsumsi oleh anggota dari kelompok budaya yang lain (Samovar, L. A., Porter, R. E. dan McDaniel, 2014). Dengan kata lain, komunikasi antarbudaya meliputi interaksi antara orangorang yang mempunyai perbedaan dalam persepsi budaya dan sistem simbol yang signifikan untuk mengubah aktivitas komunikasinya. Komunikasi tersebut terjadi baik langsung (tatap muka) ataupun melalui sebuah medium.

Sejak perkembangan teknologi internet yang terus mengalami kemajuan, komunikasi antarbudaya pada masyarakat multikultural tidak hanya berlangsung melalui tatap muka. Internet mendukung terjadinya komunikasi antarbudaya dalam sebuah ruang siber (cyberspace) tanpa dibatasi ruang dan waktu. Ruang siber merupakan ruang konseptual di mana semua kata, hubungan manusia, data, kesejahteraan, dan juga kekuatan dimanifestasikan oleh setiap orang melalui teknologi computer mediated communication (Rheingold dalam Nasrullah, 2012).

Salah satu medium yang dijadikan wadah dalam melakukan komunikasi antarbudaya dengan dukungan koneksi internet adalah media sosial. Berdasarkan hasil survei Asosiasi Penyedia Jasa Internet Indonesia (APJII) pada tahun 2016 menunjukkan bahwa konten media sosial memiliki penetrasi paling tinggi diakses oleh masyarakat Indonesia yakni sebesar 97,4\%. Dalam survei yang sama, aktivitas yang paling tinggi dilakukan di media sosial adalah berbagi informasi dengan capaian angka persetujuan responden sebesar 97,5\% (APJII, 2016).

Media sosial memungkinkan para penggunanya dengan mudah berpartisipasi, berbagi, dan menciptakan informasi. Media sosial pun memudahkan interaksi sosial di antara anggota masyarakat multikultural bersifat interaktif dengan berbasis teknologi internet (Utami \& Triyono, 2011). Jenis media sosial ini beragam dan terus mengalami perkembangan dari waktu ke waktu. Beberapa jenis media sosial tersebut ada yang berbentuk jejaring sosial, microblogging platform, jejaring, berbagi foto dan video, podcast, chat rooms, message board, forum, mailing list, dan lain-lain.

Dalam media sosial, setiap orang dari berbeda latar belakang budaya dapat berperan sebagai produsen sekaligus konsumen informasi. Hal tersebut memungkinkan setiap individu ketika berkomunikasi di media sosial membawa asumsi nilai-nilai, ekspektasi, kebiasaan verbal dan non verbal, serta aturanaturan yang dianutnya ketika mereka mengonsumsi atau memproduksi informasi. Jika terjadi ketidaksesuaian, maka potensi terjadinya konflik budaya akan semakin besar.

Terjadinya konflik sebenarnya suatu hal yang normal, bahkan suatu waktu jika dikelola dengan baik dapat semakin menguatkan hubungan (Martin \& Nakayama, 2010). Tetapi konflik dalam konteks hubungan interpersonal, jika tidak dikelola dan diselesaikan dengan baik, tidak jarang mengganggu bahkan memutus hubungan interaksi antarindividu. Apalagi jika pemicu konflik berkaitan dengan isu SARA, maka potensi terjadi gangguan antarindividu semakin besar. Isu SARA juga menjadi faktor utama penyebab terjadinya konflik dalam masyarakat multikultural (Liliweri, 2005).

Beberapa bulan terakhir pelaksanaan pemilihan kepala daerah (pilkada) serentak tahap kedua selesai dihelat. Dalam rangkaian pesta demokrasi tersebut, terdapat salah satu 
proses pilkada yang menyita banyak perhatian masyarakat, yakni pilkada di Provinsi Daerah Khusus Ibukota (DKI) Jakarta 2017.

Pilkada DKI Jakarta tahun 2017 diikuti oleh tiga pasangan calon. Pasangan pertama adalah Agus-Sylvi, pasangan kedua Basuki Tjahaja Purnama (Ahok) - Djarot Syaiful Hidayat dan pasangan ketiga Anies Baswedan - Sandiaga Uno. Pilkada DKI Jakarta 2017 ini terjadi dalam dua putaran, yang mana pada putaran kedua pasangan kedua dan ketiga kembali bertarung untuk merebut jumlah suara di DKI Jakarta.

Selama putaran pertama dan kedua Pilkada DKI Jakarta 2017, banyak masyarakat dari berbagai daerah luar Jakarta turut menyoroti Pilkada DKI Jakarta. Bahkan Kompas.com memberitakan bahwa perhelatan Pilkada DKI Jakarta seperti rasa pemilihan presiden (Tashandra, 2017). Selain banyaknya tokoh politik yang turun tangan sebagaimana yang diberitakan Kompas.com pada proses Pilkada DKI Jakarta, dalam perhelatan demokrasi ini sangat kental dengan isu SARA yang tidak jarang menimbulkan konflik. Selain karena salah satu calon gubernur (cagub) yang berasal dari SARA kelompok minoritas, ditambah lagi terdapat salah satu cagub tersebut terbentur pada kasus dugaan penistaan suatu agama mayoritas, sehingga konflik berkenaan dengan SARA, khususnya meruncing pada agama tak dapat dihindari. Ketua Badan Pengawas Pemilu, Muhammad pun menyatakan bahwa Pilkada DKI Jakarta 2017 paling rentan terjadi konflik yang dipicu isu SARA (Erdianto, 2016). Bahkan seorang pengamat militer dan intelejen, Susaningtyas Nefo Handayani Kertopati berpendapat bahwa konflik isu SARA dalam pusaran Pilkada DKI Jakarta sangat berbahaya. Konflik tersebut dapat berdampak pada kerukunan dan keutuhan bangsa Indonesia yang memiliki masyarakat multikultur (Hidayatullah, Arsito, dan Tanjung, 2017).

Konflik isu SARA khususnya yang berkaitan dengan dugaan penistaan agama dan merebaknya amanah memilih pemimpin muslim bagi agama Islam dalam Pilkada DKI Jakarta 2017 terus "digoreng" dan dimanfaatkan untuk kepentingan politik oleh segelintir orang.

Ini tidak hanya terjadi dalam proses komunikasi dunia nyata, tetapi juga terjadi secara masif di media sosial. Hal tersebut sebagaimana yang disampaikan dalam republika.co.id yang memberitakan bahwa isu SARA pada Pilkada DKI Jakarta menyebar karena media sosial yang tidak terkendali (Satria, 2016).

Salah satu media sosial yang tidak luput dari terjadinya konflik yang diakibatkan isu SARA adalah aplikasi ruang obrolan (chat room) WhatsApp. Dalam aplikasi WhatsApp seseorang dapat mengirim dan menerima berbagai macam media antarpengguna seperti teks, foto, video, dokumen, lokasi, juga panggilan suara, dan video. WhatsApp juga memungkinkan suatu kelompok dari latar belakang budaya yang berbeda tetapi memiliki suatu kepentingan yang sama bergabung dalam sebuah grup yang memfasilitasi anggota untuk membagi dan menerima informasi dalam grupnya di dunia maya.

Bentuk pengelompokkan grup dalam WhatsApp beranekaragam. Ada yang didasarkan karena kesamaan kepentingan profesi, hobi, pekerjaan, jabatan, lingkungan, pendidikan, pendidikan formal atau nonformal, dan lain-lain. Dalam grup tersebut, terdapat admin yang mungkin lebih satu orang dan anggota dengan jumlah maksimal mencapai 256 akun WhatsApp.

Ketika rangkaian pelaksanaan Pilkada DKI Jakarta 2017, tidak hanya grup WhatsApp yang berdomisilikan anggota di wilayah DKI Jakarta, ada juga masyarakat luar DKI Jakarta yang turut larut menerima dan membagikan pesan bermuatan SARA khususnya yang berkaitan dengan agama para pasangan cagub dan wakilnya di Pilkada DKI Jakarta 2017. Apalagi ditambah dengan adanya dugaan penistaan agama mayoritas oleh salah satu cagub yang memeluk agama minoritas, penyebaran pesan bermuatan SARA semakin marak di dalam grup WhatsApp, padahal anggota grup bersifat heterogen, termasuk berbeda agama. Karena beragamnya latar belakang budaya anggota dalam grup WhatsApp, maka konflik pun 
tidak dapat dihindarkan dalam sebuah grup WhatsApp.

Menurut pengamatan penulis, selama proses pelaksanaan Pilkada DKI Jakarta 2017, tidak sedikit pihak yang menyadari atau bahkan merasakan terjadinya konflik dalam sebuah grup WhatsApp yang diakibatkan penyebaran atau penerimaan informasi yang bermuatan isu SARA. Hal ini menjadi salah satu alasan bagi beberapa pihak untuk enggan melakukan atau bahkan memutuskan komunikasi dalam grup WhatsApp. Bukan hanya bagi yang berbeda latar belakang budaya khususnya agama, beberapa pihak yang berlatarbelakang budaya sama tetapi tidak setuju atau bertentangan dengan informasi yang dibagikan dalam suatu grup, juga merasakan ketidaknyamanan dan pada akhirnya mengganggu komunikasi dan interaksi dalam suatu grup WhatsApp. Jika hal ini sudah terjadi maka konflik tidak dapat lagi dihindarkan.

Konflik memiliki berbagai tipe bergantung kepada sudut pandang yang dipilih. Dalam tulisan ini penulis memandang tipe konflik berdasarkan cara memandang peristiwa atau isu (Liliweri, 2005). Isu yang yang dipandang merupakan isu SARA yang terjadi selama perhelatan Pilkada DKI Jakarta 2017. Hal ini menarik karena isu SARA yang juga dikaitkan dengan penistaan agama begitu hebat dampaknya pada Pilkada DKI Jakarta 2017.

Di daerah lain (baik provinsi, kabupaten, atau kota) isu SARA tidak terlalu memiliki dampak dominan, seperti halnya di Kalimantan Barat dan Kalimantan Tengah di mana gubernur terpilih yang memimpin dua periode berasal dari kalangan agama minoritas, padahal mayoritas penduduk kedua daerah tersebut beragama muslim.

Dalam tulisan ini, penulis juga akan menekankan perhatian pada konflik isu SARA yang terjadi pada anggota yang multikultural dalam sebuah grup di media sosial. Oleh karenanya, praktik multikulturalisme tidak dapat dipisahkan dalam pembahasan tulisan ini. Multikulturalisme merupakan konsep yang menjelaskan dua perbedaan makna yang saling berkaitan. Jika mengacu pada salah satu pengertian multikulturalisme (Liliweri, 2005), maka multikulturalisme sebagai kondisi kemajemukan kebudayaan dari suatu masyarakat. Kondisi ini diasumsikan dapat membentuk sikap toleransi. Kedua, multikulturalisme sebagai seperangkat kebijakan pemerintah pusat yang dirancang sedemikian rupa agar seluruh masyarakat dapat memberikan perhatian kepada semua kebudayaan dari berbagai etnik atau bangsa.

Berdasarkan penjelasan di atas, penulis merumuskan masalah penelitian ini sebagai berikut: Bagaimanakah konflik isu SARA pada Pilkada DKI Jakarta 2017 terjadi di obrolan grup WhatsApp dengan anggota yang multikultural?

Adapun tujuan dilakukannya penelitian ini adalah untuk mengetahui konflik isu SARA yang pada Pilkada DKI Jakarta 2017 yang terjadi di obrolan grup WhatsApp dengan anggota yang multikultural.

Pada tulisan ini, ada beberapa harapan peneliti yang berkenaan dengan signifikansi teoretis dan praktis. Dalam signifikansi teoretis, tulisan ini diharapkan dapat memberikan kontribusi tentang gambaran terjadinya konflik di dalam suatu grup media sosial dan strategi manajemen konflik apa saja yang dapat dilakukan individu jika terjadi konflik dalam media sosial. Adapun signifikasi praktis yang diharapkan adalah peneliti berharap bahwa hasil tulisan ini dapat menjadi masukan bagi individu yang menggunakan ataupun bergabung dalam suatu grup di media sosial. Masukan tersebut berkenaan dengan etika dan kesadaran diri (mindfullness) komunikasi antarbudaya dalam grup yang anggotanya multikultur dan pertimbangan apa saja yang harus diperhatikan ketika membentuk grup di media sosial serta membagikan pesan di media sosial.

\section{LANDASAN KONSEP}

\section{Penelitian Terdahulu}

Penelitian terdahulu yang berkaitan dengan konflik isu SARA serta penelitian tentang media sosial, di antaranya Humaedi (2014) yang telah meneliti "Kegagalan 
Akulturasi Budaya dan Isu Agama dalam Konflik Lampung".

Penelitian tersebut menggunakan metode penelitian kualitatif dengan strategi penelitian etnografi.

Hasilnya menunjukkan bahwa kegagalan akulturasi budaya antara suku Lampung adalah akar masalah dari konflik Lampung. Interaksi sempit karena ketiadaan ruangruang bersama dalam perjumpaan lintas budaya telah menyebabkan kegagalan akulturasi yang memungkinkan tidak pernah terciptanya pemahaman dan upaya kolaborasi berbagai budaya dapat dilakukan.

Jati (2013) membahas mengenai Kearifan Lokal sebagai Resolusi Konflik Keagamaan. Hasil penelitiannya menunjukkan bahwa konflik Maluku telah diselesaikan melalui perjanjian damai Malino tahun 2002 dan 2003, namun demikian potensi konflik di akar masyarakat dapat dikurangi melalui nilai-nilai kearifan lokal. Pela gandong sebagai kearifan lokal mempunyai peran penting dalam rekonsiliasi dengan menyatukan kembali solidaritas masyarakat yang terpecah selama konflik. Selain halnya kearifan lokal, representasi dalam birokrasi juga memegang peran utama dalam mereduksi kesenjangan sosial antara elemen masyarakat di Maluku.

Selanjutnya Zeitzoff (2011) meneliti tentang Using Social Media to Measure Conflict Dynamics: An Application to the 2008-2009 Gaza Conflict. Penelitiannya menggunakan metode kuantitatif dengan teknik analisis isi di twitter dan sumber media sosial lainnya selama konflik Gaza (20082009). Penulis menggunakan vektor autoregression untuk mengukur perubahan dinamika respon militer Israel dan Hamas segera setelah dua titik penting dalam konflik: pengenalan pasukan darat Israel dan pemungutan suara Dewan Keamanan PBB. Hasil penelitian menunjukkan bahwa tanggapan Hamas dan Israel terhadap provokasi oleh pihak lain meningkat (keduanya sekitar dua kali lipat) segera setelah invasi darat, namun setelah pemungutan suara Dewan Keamanan PBB, tanggapan Israel terputus setengah, sementara Hamas sedikit meningkat.
Sedangkan dalam tulisan ini, penulis akan membahas dan menganalisis mengenai konflik antarbudaya yang disebabkan isu SARA dalam suatu grup WhatsApp dengan anggota grup yang multikultural. Penulis akan melihat perspektif individu sebagai makhluk sosial yang unik dalam memaknai suatu konflik yang diakibatkan isu SARA dan terjadi di media sosial dengan kasus yang terjadi di dalam grup WhatsApp.

\section{WhatsApp sebagai Media Sosial}

Ada beberapa pengertian media sosial yang dikemukakan oleh para ahli di antaranya, Boyd dalam Nasrullah (2015) menyebutkan bahwa media sosial adalah kumpulan perangkat lunak yang memungkinkan individu maupun komunitas untuk berkumpul, berkomunikasi, dan dalam kasus tertentu saling berkolaborasi atau bermain. Media sosial memiliki kekuatan pada user generated content, di mana konten dihasilkan oleh pengguna bukan oleh editor seperti halnya di institusi media massa. Dijk dalam Nasrullah (2015) menjelaskan media sosial ialah platform media yang memfokuskan pada eksistensi mereka yang memfasilitasi mereka dalam beraktivitas maupun berkolaborasi.

Ada hal lain juga yang membedakan media konvesional (first media age) dan media baru (second media age) termasuk media sosial WhatsApp, yaitu pola penyebaran pesan. Jika dalam media konvensional sifatnya one to many, media baru termasuk media sosial dapat bersifat one to many atau many to many (Nasrullah, 2012). WhatsApp merupakan salah satu media sosial yang termasuk pada aplikasi chat rooms (ruang obrolan). Sejauh terhubung dengan jaringan internet, WhatsApp membantu individu maupun kelompok melakukan interaksi dan komunikasi secara real time (Kristo, 2013).

\section{Grup WhatsApp sebagai Komunitas Virtual}

Komunitas virtual adalah kumpulan pengguna (user) yang dibentuk secara online yang masing-masing menggunakan identitas nyatu atau rekaan (avatar) serta informasi 
online tertentu untuk melakukan komunikasi atau interaksi secara terus-menerus melalui mediasi jaringan komputer (Nasrullah, 2012). Saling berinterkasinya para pengguna WhatsApp dalam suatu grup yang telah dibentuk atas dasar kesamaan suatu kepentingan (hobi, alumni instansi pendidikan, pekerjaan, profesi, dan lain-lain), disadari maupun tidak membentuk sebuah komunitas baru, yakni komunitas virtual. Anggota grup WhatsApp ini saling berinteraksi dan berkomunikasi sesuai dengan kepentingan kelompoknya. Anggota grup WhatsApp dipandang sama ketika melihat pada kepentingan dasar membentuk grup WhatsApp, misalnya grup WhatsApp yang dibentuk karena hobi, maka seluruh anggota akan memiliki hobi yang sama, tetapi dalam perspektif lain anggota tersebut yang juga dipandang berbeda. Ini menunjukkan ketika terjadi kesamaan maka tiap anggota sebagai ingroup dalam satu konteks (dasar pembentukkan grup) dan anggota outgroup dalam konteks lain. Oleh karenanya, konsep multikultural dalam suatu grup WhatsApp tidak dapat dihindari, ketika terjadi perbedaan budaya (termasuk SARA) pada konteks lain.

\section{Masyarakat Multikultur}

Masyarakat multikultur saat ini terus tumbuh dari waktu ke waktu. Mereka ini adalah yang hidup berdampingan dalam dua atau lebih budaya. Mereka sering kali berupaya untuk menyesuaikan dua atau lebih perbedaan nilai, norma, pandangan dunia, atau gaya hidup (Martin \& Nakayama, 2010). Selain membedakan identitas multikultural berdasarkan ras dan etnis, ada identitas multikultural yang didasarkan pada agama, orientasi seksual, atau identitas lainnya (Martin \& Nakayama, 2010), terdiri dari beragam SARA menjadikan masyarakatnya tergolong pada masyarakat multikultur.

\section{Tipe Konflik}

Konflik merupakan gangguan antara dua atau lebih individu atau kelompok karena adanya ketidaksesuaian persepsi atas tujuan, nilai, harapan, proses, atau hasil (Martin \& Nakayama, 2010).
Konflik antarbudaya adalah konflik yang terjadi antara dua atau lebih budaya. Gudykunst (2003) mengatakan bahwa konflik terjadi ketika aktivitas yang tidak cocok terjadi. Konflik tidak dapat dihindari dalam sebuah hubungan, ia akan terjadi baik diinginkan atau tidak. Ketika konflik timbul, baik dari kedua belah pihak atau satu pihak menyadari bahwa konflik itu ada. Komunikasi adalah medium di mana konflik itu diciptakan dan dikelola (Gudykunst, 2003).

Ada dua orientasi mengenai konflik (Martin \& Nakayama, 2010). Orientasi pertama, konflik sebagai kesempatan (conflict as opportunity) dan orientasi kedua konflik sebagai perusak (conflict as destructive). Menurut Augsburger dalam Martin \& Nakayama (2010) ada empat asumsi dasar dalam pendekatan yang memandang konflik sebagai kesempatan, yaitu konflik merupakan sebuah hal yang normal dan proses yang bermanfaat; semua masalah dapat berubah melalui negosiasi; konfrontasi dan konsiliasi langsung dihargai (memiliki nilai); konflik merupakan sebuah negosiasi ulang yang diperlukan dari sebuah kontrak yang tersirat pendistribusian kembali kesempatan, pelepasan ketegangan, dan pembaharuan hubungan.

Sedangkan dalam pendekatan yang memandang orientasi konflik sebagai perusak, Augsburger dalam Martin \& Nakayama (2010) menyatakan empat asumsi dasarnya yaitu, konflik adalah sebuah gangguan yang merusak kedamaian; Sistem sosial tidak dapat disesuaikan untuk memenuhi kebutuhan anggota; Sebaliknya, anggota harus menyesuaikan diri dengan nilai yang ditetapkan; Konfrontasi bersifat destruktif dan tidak efektif; Sengketa harus disiplin.

\section{Mengelola Konflik}

Konflik dapat diselesaikan dengan cara yang berbeda sesuai dengan situasinya. Setidaknya ada lima gaya yang dapat digunakan untuk mengelola konflik (Martin \& Nakayama, 2010), yaitu: (i) Mendominasi (dominating), di mana seseorang mencapai tujuannya dengan mengorbankan orang lain; 
(ii) Mengintegrasikan (integrating), ditandai dengan pertukaran informasi yang terbuka dan langsung dalam upaya mencapai solusi yang dapat diterima oleh kedua belah pihak; (iii) Mengompromikan (compromising), strategi yang melibatkan pembagian dan pertukaran informasi kedua individu melepaskan sesuatu untuk saling menemukan suatu keputusan yang dapat diterima bersama; (iv) Mengalah (obliging), ditandai dengan mengecilkan perbedaan dan ketidaksesuaian sambil menekankan kesamaan; (v) Menghindar, mencerminkan perhatian rendah untuk kedua diri dan orang lain. Seseorang yang menggunakan gaya ini sering dipandang negatif, karena mencoba menarik diri, mengabaikan, atau melewati konflik.

\section{METODE PENELITIAN}

Dalam menganalisis komunikasi antarbudaya termasuk konflik antarbudaya ada tiga pendekatan yang dapat dilakukan (Martin \& Nakayama, 2010). Dalam tulisan ini penulis akan menganalisis berdasarkan data yang diperoleh dari hasil pemaknaan dan pengalaman individu terhadap realitas konflik budaya yang terjadi dalam sebuah media sosial, sehingga paradigma yang digunakan dalam tulisan ini adalah pendekatan interpretif.

Paradigma interpretif membantu penulis dalam memahami dan menjelaskan perilaku manusia dalam kelompok tertentu yang didasarkan pada asumsi bahwa pengalaman manusia itu subjektif, perilaku manusia kreatif/unik sehingga tidak bisa diramalkan/diprediksi dan budaya dibentuk serta dikelola melalui komunikasi. Selain itu, paradigma interpretif juga memandang suatu konflik antarbudaya dikelola dan dimaknai bergantung pada situasi atau konteks tertentu (Martin \& Nakayama, 2010). Pada tulisan ini penulis menggunakan metode penelitian kualitatif untuk menggali lebih dalam dari perspektif individu (Hennink, Hutter \& Bailey, 2010) mengenai suatu konflik yang diakibatkan isu SARA pada Pilkada DKI Jakarta 2017 yang terjadi di media sosial dengan kasus yang terjadi di dalam grup WhatsApp dengan anggota yang multikultural. Adapun pendekatan penelitian yang digunakan adalah Interpretative Phenomenological Analysis (IPA). IPA adalah pendekatan penelitian kualitatif yang dimaksudkan untuk memahami bagaimana individu memaknai kejadian-kejadian penting dalam kehidupannya. IPA bersifat fenomenologi karena mendalami tentang pengalaman orang (Smith, Flowers \& Larkin, 2009). Dalam konteks penelitian ini, peneliti mencoba memahami bagaimana memaknai pengalamannya ketika menjadi anggota grup WhatsApp dengan anggota yang multikultural dan di dalam grup tersebut telah terjadi penerimaan dan pembagian informasi isu SARA selama kampanye Pilkada DKI Jakarta 2017. Sebagai upaya memperoleh data yang kaya informasi dan mendalam, penulis mengumpulkan data untuk dianalisis dan dimaknai melalui wawancara dan kajian literatur.

Wawancara mendalam dilakukan kepada dua orang informan yang memiliki pengalaman dalam suatu grup WhatsApp dengan anggota yang multikultural dan di dalam grup tersebut telah terjadi penerimaan dan pembagian informasi isu SARA selama kampanye Pilkada DKI Jakarta 2017, selanjutnya konflik antaranggota tidak dapat dihindari. Adapun informan yang diwawancarai dengan identitas seperti tertera pada Tabel 1.

\section{HASIL PENELITIAN DAN PEMBAHASAN}

\section{Media Sosial WhatsApp}

Media sosial dengan berbagai jenis ragamnya memiliki keunikan tersendiri baik kekurangan maupun kelebihan yang dimilikinya. WhatsApp sebagai salah satu media sosial chat rooms terus gencar melakukan penambahan fitur. Ini dilakukan tak lain agar para pengguna terus merasakan kenyamanan dalam menggunakan WhatsApp. 
Tabel 1

Data Informan yang diwawancarai

\begin{tabular}{cccclcc}
\hline No & Inisial & $\begin{array}{c}\text { Jenis } \\
\text { Kelamin }\end{array}$ & Usia & \multicolumn{1}{c}{$\begin{array}{c}\text { Latar belakang } \\
\text { pendidikan }\end{array}$} & $\begin{array}{c}\text { Tempat } \\
\text { tinggal }\end{array}$ & $\begin{array}{c}\text { Mulai menggunakan media } \\
\text { sosial whatsaap }\end{array}$ \\
\hline $\mathbf{1}$ & AM & $\mathrm{L}$ & 33 & $\begin{array}{l}\text { S1 Psikologi } \\
\text { Pendidikan Sedang } \\
\text { menempuh S2 Ilmu } \\
\text { Komunikasi }\end{array}$ & Bekasi & Sekitar tahun 2006-an \\
& & & & & \\
$\mathbf{2}$ & VI & $\mathrm{P}$ & 35 & $\begin{array}{l}\text { S1 Ilmu Komunikasi } \\
\text { Sedang menempuh S2 } \\
\text { Ilmu Komunikasi }\end{array}$ & Tangerang & Sekitar 15 tahun lalu \\
& & & & \\
\hline
\end{tabular}

Berdasarkan data yang diperoleh dari informan, seluruhnya menyebutkan bahwa aplikasi WhatsApp telah terpasang dan digunakan semenjak digunakannya ponsel pintar (smartphone). WhatsApp digunakan dengan dua alasan, pertama memberikan kemudahan komunikasi baik antarpersonal maupun kelompok dan kedua, efisiensi biaya. Berikut adalah pernyataan informan tersebut:

Informan 1: “......saya sih pake pas udah punya smartphone...ya itu ya soalnya murah sih pake wa, gampang lagi ....di wa juga bisa komunikasi sama temen macem-macem grup lah..".

Informan 2: "saya pake sejak pake HP lah, kira-kira 15 tahun kali ya... Iya. Memudahkan komunikasi. Temen-temen juga lebih banyak yang pake aplikasi WhatsApp dibanding BB... Pertama memudahkan komunikasi, kedua hemat pulsa, ketiga supaya ga ketinggalan informasi-informasi update....".

Dari perspektif kemudahan komunikasi, peneliti memaknai bahwa kehadiran WhatsApp mampu memberikan kemudahan untuk saling berinteraksi tanpa dibatasi ruang dan waktu, bahkan WhatsApp dengan segala fitur yang dimilikinya mampu mewakili kehadiran dan atau keterlibatan fisik seseorang dalam berkomunikasi secara real time.

Hal tersebutlah yang disebut Graham sebagai interaktivitas (Nasrullah, 2012). Interaktivitas merupakan konsep yang sering digunakan untuk membedakan antara media baru dengan media konvensional.

Selain interaktivitas, adapula konsep lain yang kerap digunakan membedakan media konvesional (first media age) dan media baru (second media age) termasuk media sosial WhatsApp, yaitu pola penyebaran pesan. Jika dalam media konvensional sifatnya one to many, media baru termasuk media sosial dapat bersifat one to many atau many to many (Nasrullah, 2012). Prinsip pola penyebaran pesan one to many atau many to many terdapat dalam komunikasi pada sebuah grup WhatsApp.

Kemudahan komunikasi secara real time, tidak mengenal ruang dan waktu serta menjangkau khalayak luas tak hanya menjadi sisi positif penggunaan WhatsApp. Jika dikaitkan dengan pelaksanaan Pilkada DKI Jakarta 2017 beberapa waktu lalu, kemudahan komunikasi yang dapat dimanfaatkan individu melalui grup WhatsApp juga memiliki sisi destruktif. Sebagaimana yang disampaikan kedua informan, bahwa pesan bermuatan SARA dalam konteks Pilkada DKI Jakarta 2017 sangat marak dibagikan dan diterima oleh anggota grup WhatsApp. Tak jarang pesan yang dibagikan mengarah pada pesan bernada radikal bahkan belum terverifikasi kebenarannya dalam sebuah grup yang beranggotakan dari berbagai latar belakang budaya, khususnya SARA.

\section{Komunitas Virtual dalam Grup WhatsApp}

Grup WhatsApp merupakan salah satu bentuk komunitas virtual, karena di dalamnya terdapat kumpulan anggota dengan identitas berdasarkan nomor telepon pribadi yang melakukan komunikasi atau interaksi secara terus-menerus melalui mediasi jaringan internet. Pembentukan grup atau komunitas dalam WhatsApp terdiri dari berbagai macam 
alasan. Menurut informan bahwa grup WhatsApp ini dibentuk atas dasar kesamaan suatu kepentingan. Informan 1 mengungkapkan: "ya macem-macem ya, ada grup keluarga, kelas kuliah, alumni kuliah dulu, trus ada juga grup yang dibuat karna hobinya sama, kaya grup komunitas rokok cerutu di Bekasi banyak juga yang laen”.

Umumnya komunitas virtual ini dibentuk karena kesamaan latar belakang pendidikan, alumni suatu institusi pendidikan, hobi, pekerjaan, lingkungan perumahan, dan lainlain. Tetapi kesamaan tersebut tidak menutup terdapatnya perbedaan dalam konteks lain antarindividu dalam grup WhatsApp. Perbedaan tersebut dapat berupa perbedaan etnis, agama, atau ras. Dengan demikian, walaupun memiliki kesamaan kepentingan dalam suatu hal (ingroup), tetapi anggota grup masih memiliki perbedaan nilai (outgroup), khususnya identitas SARA. Maka tidak dapat dihindari bahwa komunikasi antarbudaya dan masyarakat multikultural juga terjadi dalam grup WhatsApp.

Ketika Pilkada DKI Jakarta 2017, pesan bermuatan SARA tidak sedikit mengalir dalam grup WhatsApp, bahkan menurut informan tidak hanya pada grup yang berdomisili di DKI Jakarta. Menurut informan 1: “...rame juga sih pas Pilkada DKI itu, tapi gak semua grup. Di grup keluarga juga pada rame, padahal kita di Bekasi... Kalo grup kuliah dulu ada juga ada temen yang terus aja tuh kirim-kirim, padahal dulu gak gitu...ya grup kuliah, dulu sih temennya gak gitu, jadi saya males aja padahal udah sempet bilang juga di grup gak gitu, tapi ya itu malah pada sewot juga ini kan agama kita, banyak deh pembelaannya....yah, jadi saya dan adalah beberapa temen lain minta izin left aja yah....yah gimana yah karena bahasannya jadi beda aja sama grupnya dan gak sesuai aja sama saya. "....ada, itu juga grup tuh yang kayak grup hobi itu rokok cerutu itu, gak ada pesen-pesen kayak gitu.... kalau ada kita kick sama semua anggota...jadi grup nya lempeng aja gak bahas agama atau sara laen ya".

Berdasarkan data di lapangan, keterkaitan antara kepentingan grup dengan informasi SARA yang disebarkan sangat jauh. Tetapi beberapa anggota, dengan mengatasnamakan membela agama dengan mudah melakukan penyebaran informasi yang mengarah pada tersudutnya suatu golongan agama tertentu dan mengarahkan untuk memilih pasangan calon tertentu.

Jika dilihat kembali secara mendasar, pilihan politik merupakan hak warga negara yang telah dijamin oleh negara. Ini juga diungkapkan informan 2: “...berkampanye dengan melibatkan unsur SARA adalah bagian dari ketidakdewasaan kita dalam berpolitik. Kita tidak siap menerima perbedaan, padahal perbedaan itulah yang menggiring demokrasi berkualitas.." Maka penulis memaknai bahwa tidak seharusnya pesan bermuatan politik dengan mengatasnamakan agama dibawa ke dalam suatu ruang diskusi yang dibentuk bukan atas dasar suatu pilihan politik atau agama tertentu. Ini menunjukkan bahwa kedewasaan berpolitik dan sikap toleransi sebagai ciri masyarakat multikultur terhadap umat agama lain masih belum ditunjukkan oleh anggota grup yang melakukan penyebaran pesan bermuatan SARA, khususnya agama di dalam grup WhatsApp.

Informasi atau pesan yang dikomunikasikan dan didiskusikan dalam grup WhatsApp seharusnya adalah pesan yang sesuai dengan dasar dibentuknya grup, sehingga rentang kesamaan antaranggota masih tinggi. Berbeda halnya jika pesan yang disebarkan atau diterima bukan berangkat dari kesamaan anggota grup (misalnya nilai budaya lain seperti agama atau suku lain), maka ketidaksesuaian terhadap persepsi tujuan, nilai, harapan, proses atau hasil yang termuat dalam pesan tak dapat dihindari (Martin \& Nakayama, 2010), inilah sumber awal terjadinya konflik.

\section{Tipe Konflik dalam Grup WhatsApp}

Pesan SARA banyak muncul di media sosial dan tak jarang ini memunculkan konflik bagi penggunanya termasuk anggota grup WhatsApp yang multikultural. Hal tersebut sebagaimana diungkapkan oleh informan 2:

"Fenomena SARA sedang banyak terjadi di media sosial manapun dari kalangan awam 
hingga selebritis......Saya pikir tidak wajar ya.......Ini terjadi ya karena adanya fanatisme yang berlebihan, bisa fanatisme terhadap partai tertentu, golongan tertentu, atau komunitas tertentu.

“... ini ya jelas ya ada yang dirugikan. Perbedaan adalah hak asasi tiap orang. Pihak yang dirugikan biasanya left dari grup WA atau mereka berkomentar supaya anggota yang lain yang memiliki fanatisme berlebihan lebih bijaksana menyikapi perbedaan".

Pada masyarakat multikultur biasanya didasarkan pada perbedaan ras, etnis, agama, jenis kelamin ataupun identitas lainnya (Martin \& Nakayama, 2010). Keberagaman tersebut akan berpotensi terjadinya ketidaksesuaian terhadap persepsi tujuan, nilai, harapan, proses, atau hasil. Hal ini pun diungkapkan Liliweri (2005), bahwa isu yang berkaitan nilai atau keyakinan agama yang berbeda-beda dalam suatu masyarakat multikultur menjadi salah satu potensi sumber terjadinya konflik.

Pada konteks Pilkada DKI Jakarta 2017, keberagaman SARA khususnya agama juga menjadi salah satu isu yang bergulir dalam diskusi komunitas virtual grup WhatsApp dan berdampak terjadinya konflik.

Berdasarkan data dari informan, dikemukakan bahwa konflik akibat isu SARA yang cukup marak saat Pilkada DKI Jakarta 2017 dalam suatu grup WhatsApp yang tidak dapat dicegah atau diminimalisir akan memberikan dampak yang lebih jauh yaitu terputusnya interaksi dan komunikasi dengan komunitas virtual grup WhatsApp. Dengan merujuk pada hal-hal yang diungkapkan informan tersebut, penulis memaknai bahwa orientasi konflik akibat isu SARA yang terjadi di grup WhatsApp dengan anggota grup multikultural, mengarah pada orientasi konflik yang merusak (conflict as destructive).

Hal ini terlihat karena terjadinya konflik dapat merusak kedamaian yang terjadi di dalam grup di mana muncul ketidaknyamanan beberapa anggota grup dan dampak lebih jauh terhentinya interaksi anggota yang memiliki perbedaan nilai ataupun persepsi.

\section{Mengelola Konflik Akibat Isu SARA dalam Grup WhatsApp}

Ketika konflik tak lagi dapat dihindarkan pasca penyebaran dan penerimaan pesan bermuatan SARA yang dikaitkan dengan Pilkada DKI Jakarta 2017, anggota grup yang merasakan ketidaksesuaian akan melakukan pengelolaan konflik tersebut. Menurut informan, anggota grup yang memiliki nilai berbeda biasanya pada tahap awal ada yang mencoba menetralisir dan mengingatkan kepada anggota yang menyebar isu SARA untuk bersikap bijak dan menyadari bahwa anggota grup multikultural serta mengajak para anggota untuk kembali berdiskusi/berkomunikasi sesuai dengan tujuan pembentukan grup. Ini pada beberapa grup berhasil dilakukan sehingga konflik pun tidak berdampak lebih lanjut. Hal tersebut sebagaimana diungkapkan informan 2: “... ya ada grup yang memang kental banget unsur SARA-nya. Tapi anggota-anggota grup yang lain banyak yang menengahi jadi bisa cooling down dan gak jadi radikal".

Tetapi informan juga menyatakan bahwa ada beberapa anggota dalam grup lain yang masih sulit menerima masukan dan terus menyebarkan pesan bermuatan SARA ketika Pilkada DKI Jakarta 2017. Informan menyatakan bahwa hal tersebut masih terjadi karena anggota yang menyebarkan pesan isu SARA tidak memiliki kedewasaan dalam berpolitik dan kurang menyadari bahwa anggota grup terdiri dari berbagai latar belakang budaya berbeda serta menyadari bahwa negara Indonesia bukan hanya dimiliki atau dikuasai oleh agama tertentu. Saat penyebaran pesan bermuatan SARA terus dilakukan, anggota yang merasakan ketidaksesuaian dengan hal tersebut umumnya memutuskan untuk meninggalkan grup dengan menyampaikan alasan terlebih dahulu. Biasanya alasan yang paling sering dikemukakan adalah bahwa pesan yang disampaikan dalam grup kerap banyak yang tidak sesuai dengan tujuan pembentukkan grup dan untuk menghindari ketidaknyamanan. Hal tersebut sebagaimana dinyatakan informan 1: "Kalo grup kuliah dulu ada juga ada temen yang terus aja tuh kirim-kirim, padahal dulu gak gitu...ya grup 
kuliah, dulu sih temennya gak gitu, jadi saya males aja padahal udah sempet bilang juga di grup gak gitu, tapi ya itu malah pada sewot juga ini kan agama kita, banyak deh pembelaannya...yah, jadi saya dan adalah beberapa temen lain minta izin left aja yah....yah gimana yah karena bahasannya jadi beda aja sama grupnya dan gak sesuai aja sama saya".

Berdasarkan data lapangan di atas, penulis memaknai bahwa dalam mengelola konflik akibat isu SARA terdapat dua jenis strategi yang dilakukan oleh anggota yakni strategi mengompromikan (compromising) dan strategi menghindar (avoiding). Strategi mengompromikan dilakukan pada tahap awal yang terlihat ketika konflik mulai terdeteksi dan para anggota melakukan pembagian informasi untuk tidak mengunggah pesan bertendensi SARA dan dikaitkan dengan Pilkada DKI Jakarta 2017. Ini dilakukan untuk saling menemukan suatu keputusan yang dapat diterima bersama, sehingga muncul kesepakatan dan anggota grup kembali pada nilai kesamaan seluruh anggota. Sedangkan strategi menghindar dilakukan ketika ada anggota grup yang memutuskan keluar dari grup karena masih ada anggota grup yang masih sulit menerima masukan dan terus menyebarkan pesan bermuatan SARA ketika Pilkada DKI Jakarta 2017.

\section{Temuan Penelitian}

Dalam penelitian ini peneliti lebih menekankan pada bagaimana pengelolaan konflik yang diakibatkan isu SARA ketika Pilkada DKI Jakarta 2017 yang terjadi dalam grup WhatsApp. Akan tetapi penulis menemukan suatu hal menarik dengan melihat dan memaknai strategi mengelola konflik. Di sini terlihat bahwa pada tahap awal terjadinya konflik, terdapat anggota grup yang multikultur mencoba menetralisir dan mengingatkan kepada anggota yang menyebar isu SARA untuk bersikap bijak dan menyadari bahwa anggota grup WhatsApp adalah multikultur, serta mengajak para anggota untuk kembali berdiskusi/berkomunikasi sesuai dengan tujuan pembentukan grup. Seperti halnya diungkapkan informan 2: “...ya ada grup yang memang kental banget unsur SARA-nya.

Tapi anggota-anggota grup yang lain banyak yang menengahi jadi bisa cooling down dan ga jadi radikal". Berdasarkan penelitian ini, penulis menemukan bahwa terdapat anggota grup WhatsApp yang berperan untuk menjembatani ketidaksesuaian yang terjadi karena penyebaran dan penerimaan pesan isu SARA.

Secara konseptual anggota grup tersebut dapat berperan sebagai cultural brokers. Hal ini sebagaimana rujukan literatur yang dijelaskan oleh Martin \& Nakayama (2010), bahwa dalam suatu masyarakat multikultur terdapat anggota masyarakat dalam hal ini anggota grup WhatsApp yang berperan sebagai cultural brokers. Berdasarkan pengalaman informan, anggota grup yang biasanya memiliki peran sebagai cultural brokers ialah mereka yang memiliki pemikiran bahwa politik dan agama merupakan hak manusia yang bersifat pribadi dan dijamin oleh negara, sehingga harus bertoleransi satu sama lain. Selain itu, mereka juga memiliki pandangan tentang keberagaman bangsa Indonesia yang berbhinekatunggalika. Hal tersebut terlihat pada pernyataan informan yang juga memiliki pengalaman sebagai penengah dalam konflik yang pernah terjadi, "Iya bersikap dewasa dalam berpolitik, menghargai perbedaan, dan memberikan kebebasan ketika ada anggota lain yang memiliki pandangan politik berbeda...... Ingat Indonesia dibangun ada semboyan Bhinneka Tunggal Ika....".

Temuan mengenai cultural brokers dalam penelitian ini menjadi salah satu hal yang menarik dan dapat dikaji lebih mendalam pada penelitian selanjutnya. Dalam penelitian selanjutnya, cultural brokers dapat menjadi unit analisis tersendiri sehingga dapat menggali lebih pengalaman.

Berdasarkan analisis, diskusi, dan temuan di atas, konflik karena isu SARA antaranggota grup dalam WhatsApp yang anggotanya multikultur sebenarnya dapat dicegah sehingga keharmonisan hubungan sosial antarnggota serta aliran komunikasi kelompok dalam grup dapat terjaga. Hal ini dilakukan dengan menyadari bahwa segala 
interaksi dan komunikasi yang terjadi dalam suatu grup WhatsApp tidak dapat terlepas dari konteks komunikasi antarbudaya. Dengan demikian, perlu kiranya setiap individu yang berkomunikasi dan berinteraksi dalam grup WhatsApp menerapkan kesadaran diri dan beretika komunikasi antarbudaya.

Kesadaran diri ini penting agar anggota grup mengetahui identitas dan latar belakangnya. Dengan memahami bahwa identitas individu sebagai bangsa Indonesia adalah bangsa yang multikultur dan mengakui terhadap perbedaan serta melakukan toleransi, maka anggota grup dapat menyadari mana perilaku atau pesan yang harus atau tidak dibagikan dan disebarkan dalam suatu grup WhatsApp. Kesadaran diri terhadap latar belakang pembentukan grup WhatsApp juga penting dilakukan, sehingga individu juga mengetahui pesan apa yang dapat dikomunikasikan sesuai dengan kepentingan dan tujuan yang sama pembentukkan grup WhatsApp. Kesadaran diri dibutuhkan agar setiap individu menyadari berasa dari identitas budaya apa dan latar belakang apa (Martin \& Nakayama, 2010). Dengan kesadaran tersebut individu dapat melakukan pilihan dengan sadar terhadap realitas yang dihadapinya.

Selain itu, anggota grup WhatsApp dengan anggota yang multikultur juga harus mementingkan dan menerapkan etika ketika berkomunikasi dengan anggota grup yang multikultur. Ketika bergabung dengan grup yang multikultur, individu harus memiliki kemampuan menilai kebiasaan-kebiasaan apa saja yang tergolong beretika dan tidak yang muncul pada beragam budaya. Penilaian tersebut kemudian diterapkan ketika individu melakukan komunikasi dalam grup WhatsApp dengan anggota yang multikultur. Hal tersebut penting untuk meminimalisir terjadinya konflik.

Selain itu, dengan merujuk pada beberapa pemikiran Joseph A. Devito (Lee, Neeley \& Stewart, 2012) maka individu dalam grup WhatsApp yang multukultur mengakui bahwa perbedaan itu ada dalam setiap kelompok. Selain itu, perlu juga menganggap bahwa perbedaan dalam suatu kelompok tidak penting, tetapi individu-individu harus mencari nilai-nilai kesamaan melalui kesadaran diri terhadap kepentingan dan tujuan yang sama ketika awal dibentuknya grup WhatsApp. Selanjutnya, individu menggunakan kesamaan itu ketika berkomunikasi dan berinteraksi dalam grup WhatsApp yang multikultur.

\section{PENUTUP}

\section{Simpulan}

Berdasarkan tulisan ini, dapat disimpulkan bahwa konflik isu SARA pada Pilkada DKI Jakarta 2017 di obrolan grup WhatsApp dengan anggota yang multikultur terjadi karena beberapa anggota grup menyampaikan pesan bukan berangkat dari kesamaan anggota grup, yakni kepentingan dan tujuan awal dibentuknya grup. Tetapi pesan, disebarkan dengan menganggap wujud pembelaan terhadap suatu agama yang dikaitkan dengan konteks Pilkada DKI Jakarta 2017, maka ketidaksesuaian terhadap persepsi tujuan, nilai, harapan, proses, atau hasil yang termuat dalam pesan tak dapat dihindari.

Dengan demikian, tipe konflik yang terjadi adalah konflik yang bersifat mengarah pada konflik yang merusak. Ketika konflik terjadi dalam grup WhatsApp, maka strategi pengelolaan konflik yang diterapkan adalah strategi mengompromikan (compromising) dan menghindar (avoiding).

Strategi mengompromikan dilakukan pada tahap awal konflik sedangkan menghindar dilakukan ketika konflik sulit untuk dikendalikan/diredam. Dalam penelitian ini, ditemukan juga bahwa ketika terjadi konflik di grup WhatsApp yang multikultur juga terdapat anggota yang berperan sebagai cultural brokers, yaitu mereka yang memiliki pemikiran bahwa politik dan agama merupakan hak yang bersifat pribadi dan dijamin oleh negara, sehingga harus bertoleransi satu sama lain. Selain itu, mereka juga memiliki pandangan tentang keberagaman bangsa Indonesia yang berbhinekatunggalika. 


\section{Saran}

Adapun implikasi yang dapat disampaikan berdasarkan tulisan ini, yakni dalam membentuk sebuah komunitas virtual di media sosial, khususnya WhatsApp penting kiranya admin anggota grup mendeklarasikan tujuan pembentukan grup dan hal apa saja yang boleh atau tidak dilakukan dalam grup tersebut. Hal ini menjadi penting, agar di kemudian hari jika terjadi ketidaksesuaian perilaku anggota grup, maka anggota yang lain dapat memberikan peringatan.

Penting pula ketika membentuk sebuah grup WhatsApp, grup dibentuk dengan meminimalisir perbedaan identitas dan latar belakang budaya. Karena semakin besar spektrum perbedaan tersebut, maka akan semakin besar pula potensi terjadinya konflik. Dan hal yang tidak kalah penting adalah segala aktivitas komunikasi dan interaksi yang dilakukan dalam grup WhatsApp harus berangkat dari kesamaan anggota grup (misalnya tujuan pembentukkan grupnya karena kesamaan hobi), hindari konten pesan yang berada di luar konteks pembentukan grup.

Selain itu, penting pula bagi para pengguna media sosial WhatsApp untuk bersikap mindfullness dalam membagikan dan menyebarluaskan informasi yang berkaitan dengan politik ataupun agama, karena kedua hal tersebut sudah menjadi ranah pribadi dan berpotensi untuk menimbulkan konflik yang bersifat dekstruktif. Dengan demikian konflik dalam grup WhatsApp diharapkan dapat diminimalisir pada kegiatan pilkada lainnya.

\section{DAFTAR PUSTAKA}

APJII (2016) Infografis, Penetrasi Dan Perilaku Pengguna Internet Indonesia Survey 2016. 2016.

Erdianto, K. (2016) Jelang Pilkada 2017, Hanya DKI Jakarta yang Paling Rawan Isu SARA. [Online]. 2016. Kompas.com. Available from:

http://nasional.kompas.com/read/2016/11/28 /17051701/jelang.pilkada.2017.hanya.dki.ja karta.yang.paling.rawan.i [Accessed: 13 May 2017].

Gudykunst, W.B. (2003) Cross Cultural and
Intercultural Communication. Thousand Oaks, California, Sage Publications, Inc.

Hennink, M., Hutter, I. \& Bailey, A. (2010) Qualitative Research Methods. Thousand Oaks, Sage Publications, Inc.

Hidayatullah, A. \& Tanjung, E. (2017) Pengamat Militer: Isu SARA di Pilkada DKI Sangat Berbahaya. [Online]. 2017. Suara.com. Available from: http://www.suara.com/news/2017/03/20/162 353/pengamat-militer-isu-sara-di-pilkadadki-sangat-berbahaya [Accessed: 13 May 2017].

Humaedi, M.A. (2014) Kegagalan Akulturasi Budaya dan Isu Agama dalam Konflik Lampung. Analisa. [Online] 21 (2), 149. Available from: doi:10.18784/analisa.v21i02.11.

Jati, W.R. (2013) Kearifan Lokal Sebagai Resolusi Konflik Keagamaan. Walisongo. 21 (November), 393-416.

Kristo, F.Y. (2013) Kisah Kelahiran Line, Kakao Talk, WeChat dan WhatsApp. [Online]. 2013. Available from: http://inet.detik.com/read/2013/05/29/11280 5/2258887/398/kisah-kelahiran-line-kakaotalk-wechat-dan-whatsapp [Accessed: 5 February 2016].

Lee, M., Neeley, G. \& Stewart, K. (2012) The Practice of Government Public Relations. London, CRC Press.

Liliweri, A. (2005) Prasangka dan Konflik: Komunikasi Lintas Budaya Masyarakat Multikultur. Yogyakarta, LKiS.

Martin, J.N. \& Nakayama, T.K. (2010) Intercultural Communication In Contexts. 5th edition. New York, McGraw-Hill.

Nasrullah, R. (2012) Komunikasi Antarbudaya di Era Budaya Siber. Jakarta, Kencana Prenada Media Group.

Nasrullah, R. (2015) Media Sosial: Perspektif Komunikasi, Budaya, dan Sosioteknologi. Bandung, Simbiosa Rekatama Media.

Samovar, L. A., Porter, R. E. dan McDaniel, E.R. (2014) Communication Between Cultures. 7th edition. Jakarta, Salemba Humanika.

Satria, L. (2016) Isu SARA Menyebar karena Media Sosial yang tidak Terkendali. [Online]. 2016. Republika.co.id. Available from:

http://www.republika.co.id/berita/nasional/u mum/16/10/27/ofplzo282-isu-saramenyebar-karena-media-sosial-yang [Accessed: 13 May 2017].

Smith, J.A., Flowers, P. \& Larkin, M. (2009) Interpretative phenomenological analysis: 
theory, method, and research. Thousand Oaks, Sage.

Tashandra, N. (2017) Pilkada Jakarta Rasa Pilpres, 'Turun Gunungnya' Mega, SBY, dan Prabowo. [Online]. 2017. Kompas.com. Available from: http://nasional.kompas.com/read/2016/09/23 /07344301/pilkada.jakarta.rasa.pil [Accessed: 13 May 2017].

Utami, A.D. \& Triyono, R.A. (2011) Pemanfaatan Blackberry Sebagai Sarana Komunikasi Dan Penjualan Batik Online Dengan Sistem Dropship Di Batik Solo 85. Speed - Sentra Penelitian Engineering dan Edukasi. [Online] 3 (3), 33-40. Available from: http://ejurnal.net/portal/index.php/speed/arti cle/view/499.

Zeitzoff, T. (2011) Using Social Media to Measure Conflict Dynamics. Journal of Conflict Resolution. [Online] 55 (6), 938969. Available from: doi:10.1177/0022002711408014. 